\title{
Leading digital transformation through an Agile Marketing Capability: the case of Spotahome
}

\author{
Ludovica Moi ${ }^{1}$ (1) Francesca Cabiddu ${ }^{1}$ (i)
}

Accepted: 28 September 2020 / Published online: 4 October 2020

(c) The Author(s) 2020

\begin{abstract}
Scholars and practitioners both acknowledge that agility is crucial in leading a digital transformation effort. However, empirical and theoretical research on agile capabilities in an international digital marketing setting is severely lacking. Drawing on qualitative research design methods, this exploratory single-case study involving the international digital firm Spotahome provides an empirical and theoretical investigation of a new marketing capability we define as an Agile Marketing Capability. We identify its key theoretical dimensions and provide empirical guidelines to facilitate its implementation. This study has important implications for international marketing managers, suggesting what strategic actions are needed to deploy agile practices in their marketing strategies and processes from a practical perspective, in the context of an Agile Marketing Capability.
\end{abstract}

Keywords Agile Marketing Capability · Marketing capabilities · International marketing $\cdot$ Digital business $\cdot$ Single-case study

\section{Introduction}

In today's business environment, firms are being pushed to rethink their business models, offerings, and processes in light of the challenges and opportunities posed by what is generally known as digital transformation (Daspit 2017; Killian and McManus 2015; Onetti et al. 2012; Rogers 2016). The term encompasses the myriad changes that digital technologies elicit in a company's business model, such as changed products and organizational structures, streamlined processes, and enhanced customer experiences (Fitzgerald et al. 2014; Hess et al. 2016). This

Ludovica Moi

ludovica.moi@unica.it

Francesca Cabiddu

fcabiddu@unica.it

1 Department of Economics and Business Sciences, University of Cagliari (Italy), Viale Sant'Ignazio 74, 09123 Cagliari, Italy 
has produced more "aggressive" marketplaces, where highly competitive, innovative and agile start-ups that leverage their abilities to quickly identify and respond to new business opportunities, are jeopardizing the stability of long-standing firms (D’Aveni et al. 2010; Roberts and Grover 2012a, b).

Scholars and practitioners alike deem marketing capabilities as a crucial source of a company's competitive advantage, especially in today's volatile markets and in international contexts. Marketing capabilities represent the means by which firms gather and exploit market knowledge to swiftly modify their businesses according to market-driven changes (Barrales-Molina et al. 2014; Bruni and Verona 2009; Orlandi 2016; $\mathrm{Xu}$ et al. 2018). The constant state of flux that characterizes the current business environment has led marketers to apply agile methods and practices to shorten cycle time, increase flexibility, and sharpen competitiveness (Barkema et al. 2002; Goldman 1995; Grewal and Tansuhaj 2001; Sebastian et al. 2017), and to swiftly adapt to market globalization (Chaffey 2010; Day 2011; Overby et al. 2006; Panda and Rath 2017). The extension of agile practices, i.e., faster production cycles, continuous improvement processes, transparency, coordination, customer engagement (Conboy 2009; Recker et al. 2017) from the software development arena to the marketing field has determined the emergence of Agile Marketing. This new marketing approach aims to reduce the gap between the "need identified" and "learning deployed" (Miles 2013; p. 22), to design more strategic and effective responses to dynamic environments (Accardi-Petersen 2011; Gera et al. 2019; Poolton et al. 2006; van den Driest and Weed 2014). Agile Marketing is rooted in a string of practices designed to quickly adjust marketing strategies in response to evolving customer needs, emphasizing speed in addressing those changes, coordination between roles and departments, transparency, and greater customer engagement (Ewel 2013).

The literature on marketing and strategy is increasingly focused on using agility to address the challenges posed by digital transformation. Studies emphasize the need to "embrace change" (O'Keeffe et al. 2016; p. 432), predict market needs and innovate (Rigby et al. 2016), and cater to customers' needs (Bock et al. 2012; Jain 1989; Theodosiou and Leonidou 2003; Vendrell-Herrero et al. 2017), especially in highly competitive, international markets (Asseraf et al. 2019; Hagen et al. 2019). Being agile means moving quickly and flexibly (Gren et al. 2015) to respond to needs and opportunities in international markets (Hagen et al. 2019). From this perspective, agility is a dynamic capability (Felipe et al. 2016; Sambamurthy et al. 2003; Teece et al. 2016), and specifically a firm's ability to stay up-to-date with market dynamics and adapt its strategies, tactics, and operations accordingly (Dubey et al. 2018; Ravichandran 2018; Zhou et al. 2018).

Despite international marketing scholars' interest in agility (Gomes et al. 2020), no studies have yet investigated agility in the context of marketing capabilities research stream. Whereas scholars have extensively discussed the positive linkage between agility and marketing performance (Alford and Page 2015; Golgeci and Gligor 2017; Zhou et al. 2018), and have recognized agility as a critical success factor in tackling international market opportunities (Vaillant and Lafuente 2019), there is a lack of research that analyses and conceptualizes the concept of agility as a specific marketing capability that enhances a company's ability to adapt to a changing international environment 
(Gomes et al. 2020; Khan 2020). We found that existing studies have neglected to understand specifically how agile capabilities might take place in international digital marketing settings, and what components may be needed to develop an appropriate Agile Marketing Capability. This is particularly important for international marketing scholars and practitioners since important tensions remain in understanding how to develop key capabilities in increasingly competitive, international marketplaces (Guo et al. 2018; Vaillant and Lafuente 2019).

The present study attempts to close this gap and provides an empirical foundation for designing a new marketing capability referred to as Agile Marketing Capability. Specifically, this study aims to: 1) investigate the concept of agility in an international digital marketing setting; 2) identify and explore the theoretical and empirical dimensions of the Agile Marketing Capability, suggesting an initial framework and key propositions; 3) provide the first definition of an Agile Marketing Capability. This study adopts a theory-building approach based on an exploratory single-case study (Eisenhardt 1989; Miles and Huberman 1984; Yin 1994), focusing the attention on the case of Spotahome, a leading company in online bookings of non-vacation home rentals.

This study contributes to extend both academic research and practice. From a theoretical perspective, we extend the literature on agility and marketing capabilities by advancing the concept of an Agile Marketing Capability. Our findings provide the empirical and theoretical dimensions that characterize such a capability organized in a framework, thereby specifying the actions necessary to enable the development of an Agile Marketing Capability. We also put forth four propositions that summarize our results, as the starting point for future theoretical and empirical research in this nascent line of inquiry. From a managerial perspective, the study offers useful guidance for managers and practitioners, particularly those who operate in digital and international business contexts, on how best to leverage digital technologies to satisfy customers in rapidly changing international contexts. In addition, the framework and propositions of this study could help marketing managers and practitioners to understand ways to develop and implement agility in marketing to improve speed, flexibility, and customer responsiveness in their international marketing strategies, operations, and tactics.

The remainder of this paper is structured as follows: Sect. 2 presents the theoretical background on agility and marketing capabilities; Sect. 3 describes the details of the single-case study methodology adopted here (i.e., case selection, data collection, data analysis process and rigor); Sect. 4 presents the research findings, identifying key dimensions of the Agile Marketing Capability organized into a theoretical framework; lastly, Sect. 5 concludes with a discussion of four propositions that summarize the study's outcomes, theoretical contributions and managerial implications, and describes certain limitations of this work as well as avenues for future research.

\section{Theoretical background}

Early research on marketing capabilities focused on the Resource-Based View, according to which firms assume an internally-driven approach to understanding and serving customers, using their internal resources and capabilities as the main 
source of a competitive advantage (Barney 1991). Over time, this early definition of a firm's marketing capabilities has been challenged by the Dynamic Capability (DC) theory (Day 2011; Teece et al. 1997), which embraced a more dynamic and open perspective, and focused on developing marketing capabilities able to respond to fast-changing environments (Bruni and Verona 2009). Drawing on DC theory, marketing capabilities are "an organization's fundamental belief for value creation in an increasingly open market environment” (Mu 2015; p. 152); hence, internal marketing resources are aligned with the dynamics of complex external environments (Day 2011; Jaakkola et al. 2010; Mu 2015; Saeed et al. 2015).

Based on this perspective, scholars conceptualized "dynamic marketing capabilities" which "reflect human capital, social capital, and the cognition of managers involved in the creation, use, and integration of market knowledge and marketing resources to match and create market and technological change" (Bruni and Verona 2009; p. 7). Dynamic marketing capabilities are crucial for firms in highly competitive scenarios; they capture the responsiveness and efficiency of cross-functional business processes in reconfiguring resources to respond to market-related changes and deliver greater customer value (Falasca et al. 2017; Fang and Zou 2009; Xu et al. 2018).

Despite the considerable body of literature that recognizes the relevance of dynamic marketing capabilities, scholars acknowledge that it is a constantly evolving topic. Firms are always looking for new ways to increase their capacity to anticipate, respond, and adapt to market changes, particularly in the face of highly competitive rivalries (Day 2011; Merrilees et al. 2011). For these reasons, recent studies have shifted attention toward "adaptive marketing capabilities," given the increasing complexity of market demands and the velocity of technological progress (Day 2011; Moorman and Day 2016). Adaptive marketing capabilities are defined as "the extensible ability to proactively sense and act on market signals, continuously learn from market experiments, and integrate and coordinate social network resources to adapt to market changes and predict industry trends" (Guo et al. 2018; p. 81). Thus, they require a firm's vigilant market learning, adaptive market experimentation, and open marketing (Day 2014).

Briefly, dynamic and turbulent business environments require firms to gather higher capacities to answer to fast-changing environments (Day 2011; Merrilees et al. 2011). In other words, firms are increasingly forced to learn how to be more agile in adapting to changing business scenarios (Chakravarty et al. 2013). Agility is defined as the dynamic capability of an organization "to manage uncertainty [...] to efficiently and effectively redeploy/redirect its resources to value-creating and value protecting (and capturing) higher-yield activities as internal and external circumstances warrant" (Teece et al. 2016; p. 8). Research in the marketing field clearly recognizes the positive linkage between agility and marketing performance (e.g., Alford and Page 2015; Golgeci and Gligor 2017; Nemkova 2017; O'Keeffe et al. 2016). Agility fosters a firm's ability to create customer value, increase its competitive advantage (Matthyssens et al. 2005), and handle market-driven changes (Tahmasebifard et al. 2017) due to the marketing teams' increased speed, coordination, customer engagement, and flexibility (Accardi-Petersen 2011; Ewel 2013; Smart 2016). In the international marketing literature agility "allows firms to better 
Table 1 Summary of key features of agility. Source: Authors' elaboration

\begin{tabular}{|c|c|}
\hline Feature & Sources \\
\hline $\begin{array}{l}\text { Continuously and quickly monitor and detect envi- } \\
\text { ronmental changes, opportunities, and threats }\end{array}$ & $\begin{array}{l}\text { Gligor et al. (2013), Li et al. (2009), Mandal (2018), } \\
\text { Sambamurthy et al. (2003), Sangari and Razmi } \\
\text { (2015) }\end{array}$ \\
\hline $\begin{array}{l}\text { Timely and resolute decision-making and innova- } \\
\text { tion }\end{array}$ & $\begin{array}{l}\text { Chen et al. (2015), Eckstein et al. (2015), Gligor } \\
\text { et al. (2013), Lu et al. (2011), Swafford et al. } \\
\text { (2006) }\end{array}$ \\
\hline $\begin{array}{l}\text { Quick access to information, multitasking teams, } \\
\text { and speed in introducing new products and } \\
\text { exploring new markets }\end{array}$ & Ismail and Sharifi (2006), Lin et al. (2006) \\
\hline $\begin{array}{l}\text { Responsiveness in identifying and responding to } \\
\text { changing needs of new or existing markets, reac- } \\
\text { tively or proactively, and adequately coordinat- } \\
\text { ing plans with the supply chain }\end{array}$ & $\begin{array}{l}\text { (Chakravarty et al. (2013), DeGroote and Marx } \\
\text { (2013), Hult et al. (2005), Li et al. (2009), Sangari } \\
\text { and Razmi (2015)) }\end{array}$ \\
\hline $\begin{array}{l}\text { Respond to market changes and customer demands } \\
\text { through an adaptive and flexible approach } \\
\text { without requiring significant strategic changes, } \\
\text { by adjusting tactics and operations according to } \\
\text { changing customer requirements }\end{array}$ & $\begin{array}{l}\text { Gligor et al. (2013), Lu et al. (2011), Overby et al. } \\
\text { (2006), Sheffi and Rice (2005) }\end{array}$ \\
\hline $\begin{array}{l}\text { Close relationships and collaboration, decentral- } \\
\text { ized decision-making, and expertise in using IT } \\
\text { to address dynamic environments }\end{array}$ & $\begin{array}{l}\text { Chakravarty et al. (2013), Felipe et al. (2016), } \\
\text { Mithas et al. (2011), Piccoli and Ives (2005), } \\
\text { Wagner et al. (2014), Zhou et al. (2018) }\end{array}$ \\
\hline $\begin{array}{l}\text { Technology integration to align with businesses } \\
\text { and facilitate effective information flow across } \\
\text { the supply chain }\end{array}$ & $\begin{array}{l}\text { Ismail and Sharifi (2006), Kearns and Sabherwal } \\
\text { (2006), Lin et al. (2006), Oh and Pinsonneault } \\
\text { (2007), Roberts and Grover (2012b), Tallon and } \\
\text { Pinsonneault (2011) }\end{array}$ \\
\hline
\end{tabular}

formulate domestic market approaches (i.e., standardization) while customizing their existing strategies to approach international markets (i.e., adaptation)," thus, it "can be defined as the ability of organization in swiftly applying marketing practices contingent upon domestic and international market situations" (Li et al. 2019; p. 2). Features of agility are summarized in Table 1.

\section{Methodology}

To explore the dynamics of this phenomenon, we selected an in-depth, inductive case study research design (Eisenhardt 1989; Miles and Huberman 1984; Yin 1994). Limited theoretical and empirical studies on agility in digital and international marketing indicate the exploratory nature of the present study. We chose the single-case study methodology as it is recommended as a useful approach in the theory-building process (Miles and Huberman 1984; Yin 1994). Since the case study methodology is crucial for "confronting theory with the empirical world" (Piekkari et al. 2009; p. 569), it allows us to explore how agile competencies in a digital and international marketing field might take place from a practical perspective. Hence, this research design is a logical choice for gathering empirical data to broaden the understanding 
of the concept of interest (Dyer and Wilkins 1991; Edmondson and McManus 2007; Stake 1995; Yin 1994).

\subsection{Case selection}

To conduct the study we followed a purposeful sampling approach (Patton 2014). We selected a case study that is highly representative of, and informative about the phenomenon of interest; in other words, an "archetypical" case that is highly suitable for accomplishing our theoretical purposes and addressing our research question (Silverman 2013; Stake 1995; Yin 1994). We focus on a company that employs digital marketing techniques in an international setting, as Agile Marketing skills are particularly important in this context and are therefore expected to be clearly observable.

With these goals, we identified Spotahome as a noteworthy case for our study that would allow us to perform empirical qualitative research on agile capabilities in a digital and international marketing setting. Several factors supported our case selection (Yin 2009), as described here.

Spotahome is a digital start-up with an international market, founded in 2014. It is a leader in the business of online bookings for non-vacation home rentals. First, we note that start-ups or recently launched firms are likely to embrace "agile" concepts, as innovation, internationalization, and technological advances require such firms to perform under conditions of high uncertainty (Ries 2011) and, in turn, to be extremely flexible (Almor 2011; Coleman and O'Connor 2008; Hoffman et al. 2013). Hence, start-ups are increasingly adopting agile practices to improve teamwork, coordination, communication, and speed in entering a marketplace (Coleman and O'Connor 2008; Hoegl and Gemuenden 2001; Pantiuchina et al. 2017; Pikkarainen et al. 2008).

Furthermore, online firms like Spotahome depend strongly on digital tools to reveal and monitor changes in international customer needs, and to pursue customercentric marketing initiatives, both of which represent critical traits of agile capabilities (DeGroote and Marx 2013; Gligor et al. 2013; Kitchens et al. 2018; Matthyssens et al. 2005). Such firms must be highly flexible, internally and externally, to adapt their marketing strategies and operations to different country and region-specific preferences. These are key features embedded in agility (Lu et al. 2011; Swafford et al. 2006). Also, by selecting this company, we differentiate our analysis from previous works that investigated better known digital platforms such as Airbnb, Amazon and Uber (e.g., Stone 2013, 2017).

Preliminary research also revealed that the company has unique features that made it an excellent candidate for the study (Eisenhardt 1989; Yin 1994). Spotahome is a digital start-up committed to providing easier home rental services, as easy as "getting a coffee," while avoiding traditional real estate agencies and preserving what customers appreciate about vacation home rental platforms. As clearly stated on its official website (http://www.spotahome.com), the company's mission is "to reinvent real estate. Make it transparent, instant, and exciting. Loved at last. Unreal estate [...] We work to teleport people into homes anywhere, so they can 
live the experience without being there. We connect with them. We bring reality to them." Spotahome seeks to arrange mid- to long-term home rentals for their customers, focusing on ease of use, communication and transparency: "The Spotahome experience removes the need for in-person viewings, saving both tenants and landlords the time and expense. We take professional photos, design floor plans, and record high-definition videos of the property and neighborhood. We also write detailed descriptions of the home and local area”.

Based on these characteristics, we concluded that Spotahome's values are strongly aligned with Agile Marketing principles (agilemarketingmanifesto.org). For example, one of Agile Marketing's highest priorities is to continuously satisfy and create value for customers and Spotahome is clearly dedicated to meeting its customers' needs. Another key aspect of Agile Marketing is viewing simplicity as essential, and Spotahome does so by declaring "embrace simplicity" as one of its priorities. Finally, Agile Marketing emphasizes collaboration and a motivating working environment, both of which play a pivotal role in Spotahome's success.

We also chose Spotahome for our case study based on having access to key informants of the firm. Indeed, we interviewed key members of the marketing department in different roles who provided extensive, detailed, and useful information concerning the company's marketing activities and performance.

These observations reinforce our view that using Spotahome for this case study would allow us to carry out our research according to our identified objectives.

\subsection{Data collection}

We collected data from various sources, namely semi-structured interviews, Spotahome's social networking sites and official website, and archival documents (e.g., reports, press reviews) to ensure data triangulation and robustness of our research findings (Benbasat et al. 1987; Dubé and Paré 2003; Eisenhardt 1989; Miles and Huberman 1984; Yin 1994). We followed a homogeneous line of inquiry (Yin 2009) to reduce the potential for misinterpretation, and to enhance the in-depth understanding of the phenomenon investigated (Hagen et al. 2019).

Primary data were collected through semi-structured interviews with key respondents who are highly knowledgeable in the marketing field (Eisenhardt and Graebner 2007). We followed a semi-structured interview protocol, which consisted of eight questions (Fontana and Frey 2000; Robson 1993) (see Appendix A). The interview protocol was developed based on the literature on agility and the Agile Marketing Manifesto (agilemarketingmanifesto.org). To ensure clarity, we pilottested the questionnaire with an Italian firm that operates in the online booking (Yin 1994), and refined the interview protocol based on feedback received about the questions' ambiguity or complexity (Van Teijlingen et al. 2001). While conducting the interviews, we asked additional exploratory questions to enrich the information gathered (Myers 2013; Taylor et al. 2015). The interviews were performed during November 2018. Each interview was recorded and transcribed (Bryman and Bell 2015; Seidman 2013), and lasted an average of $30 \mathrm{~min}$. The interviewees had different roles within the firm and were deemed as key sources of information on the 
Table 2 Summary of primary data sources

\begin{tabular}{lll}
\hline Source & Position & $\begin{array}{l}\text { Interview time } \\
\text { span (minutes) }\end{array}$ \\
\hline Semi-structured interview & Head of Brand and Communications & 28 \\
Semi-structured interview & Brand and Communications Executive & 31 \\
Semi-structured interview & Head of Digital Performance Marketing & 33 \\
Semi-structured interview & Head of Insights And Analytics & 18 \\
Semi-structured interview & Search Engine Optimization (SEO) Manager & 33 \\
Semi-structured interview & Growth and User Acquisition Coordinator & 32 \\
\hline
\end{tabular}

Table 3 Summary of secondary data sources

\begin{tabular}{lll}
\hline Source & Type & Number of items \\
\hline Social networks & Posts on Facebook & 261 posts on Facebook \\
& and Instagram & 712 posts on Instagram \\
Official website & Web page & 5 captures \\
\hline
\end{tabular}

firm's marketing processes and strategies given their responsibilities in Spotahome's marketing department (Kumar et al. 1993) (see Table 2). To ensure accuracy, interviewees were invited to review/modify the interview transcripts.

We collected secondary data from Spotahome's social networks and the official website (see Table 3). Multimedia contents shared on social networks and official website (i.e., posts, photos, and videos) were captured using NCapture, the browser application of NVivo (Moi et al. 2018). To supplement our findings, we also analyzed archival documents (e.g., reports, press reviews). This secondary data enabled us to enrich the information needed to investigate the firm's marketing strategies (Miles and Huberman 1984).

\subsection{Data analysis}

For this study, we performed a within-case analysis (Eisenhardt 1989; Eisenhardt and Graebner 2007). Using NVivo 10 software, we took a theory-building approach to look for theoretical categories or concepts in the coding process (Gibbs 2007). We conducted our data coding and analysis as follows: (1) we analyzed the data and coded key words and units of text (e.g., "adapt" and "collaboration"), extending their meaning using a list of codes (Miles and Huberman 1984); (2) we re-analyzed the data, identifying new categories and codes and comparing them with the data already coded, and triangulated the interview data with secondary data sources until we reached a saturation point (Strauss and Corbin 1998); (3) we developed a thematic analysis to identify patterns, common meanings or emerging themes (e.g., "bring improvements and innovation" and "customer-centric marketing efforts") as the investigation progressed (Aronson 1995; Boyatzis 1998); (4) we advanced the interpretation of our analysis by reflecting on its connections with the original data. 
We conducted our analysis by applying the following criteria, which are extensively used in qualitative research: credibility, transferability, dependability, and confirmability (Lincoln and Guba 2013; Shah and Corley 2006). Notably, for the credibility criteria (i.e., interviewees' trust in the researchers' understanding and interpretation of their responses), we clearly informed respondents about our research purposes and discussed our interpretations during the conversations. Regarding the transferability criteria (i.e., in-depth contextualization of information collected), we interviewed key personnel at Spotahome with different roles, to gather detailed data from different perspectives. With respect to dependability (i.e., use of various approaches and sources), we triangulated various data sources to enrich and support our understanding and interpretation. Finally, for confirmability (i.e., interpretation grounded on data collected), in explaining our research findings we incorporated direct quotes from our interviews, and supported our explanations with examples using the original data. At the end of the data analysis process, we identified a key set of relevant concepts to further our theoretical framework (see examples of this process in Table 4).

The two co-authors of this study performed the entire coding process independently and simultaneously. At each step, we ran a Coding Comparison Query and discussed any inconsistencies until achieving a Kappa coefficient ${ }^{1}$ greater than 0.75 (Bazeley and Jackson 2013).

The following key dimensions of the Agile Marketing Capability were identified: "adaptability to changing conditions," "collaborative and integrated working environment," "continual and fast pace of innovation," and "forecasting and monitoring of market needs." The study's major outcomes are discussed in the following sections.

\section{Findings}

We studied agility in an international digital marketing context by analyzing semistructured interviews, triangulated with Spotahome's social networking sites and official website, as well as additional archival documents (Table 5).

Spotahome is a digital start-up running a global marketplace, helping to drive the digitalization of the real estate rental industry. We observed how the firm works to educate customers in various countries about a different, more customized home rental experience. Our analysis reveals interesting and practical insights about how firms involved in an international marketing effort that is driven by digitalization should develop and implement an Agile Marketing Capability. Study findings are organized in a theoretical framework in which the key dimensions of the Agile Marketing Capability are represented (see Fig. 1).

\footnotetext{
1 The coefficient measures the degree of agreement between coders. A value of K-coefficient close to 1 indicates "excellent agreement", whereas a value of 0 (or less) indicates disagreement between coders.
} 


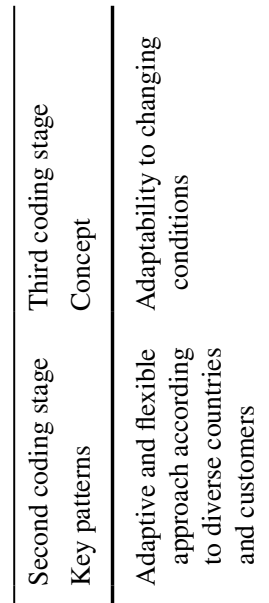

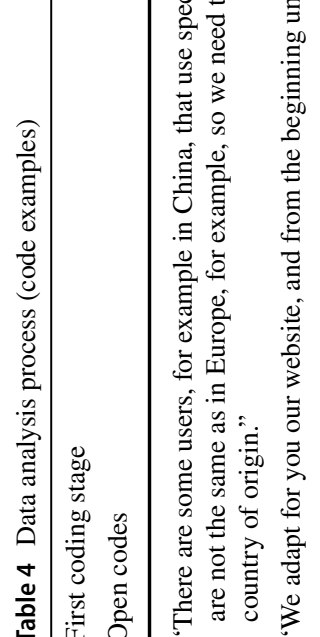

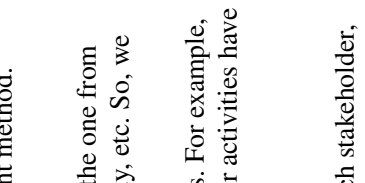

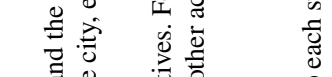
สิ 녕 岁这


ठ․

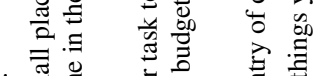
ธี่

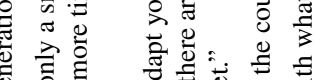


氙








ป气 च



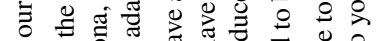
范芯

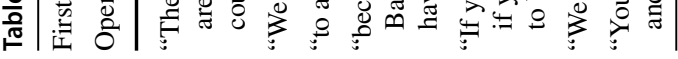




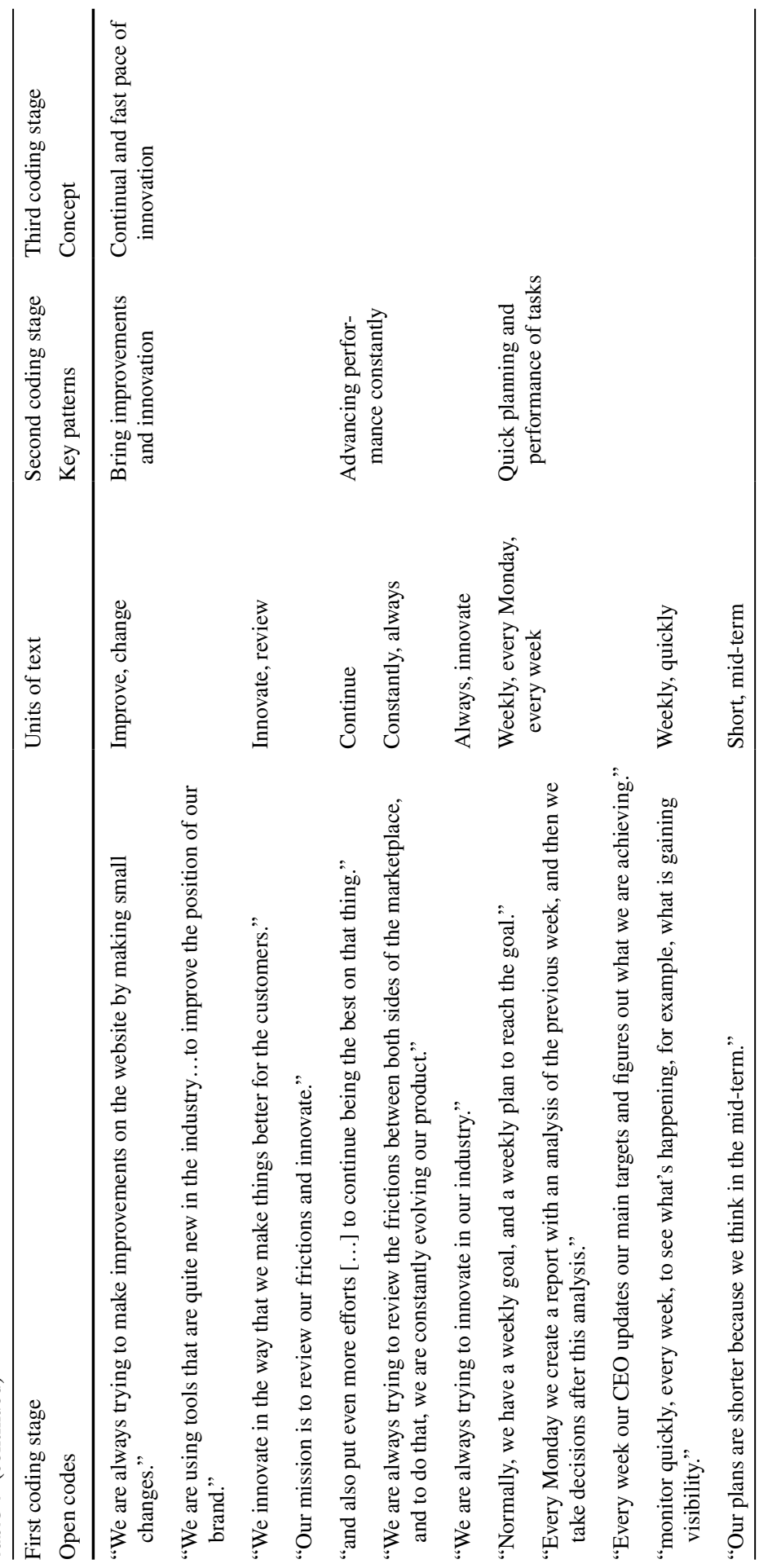




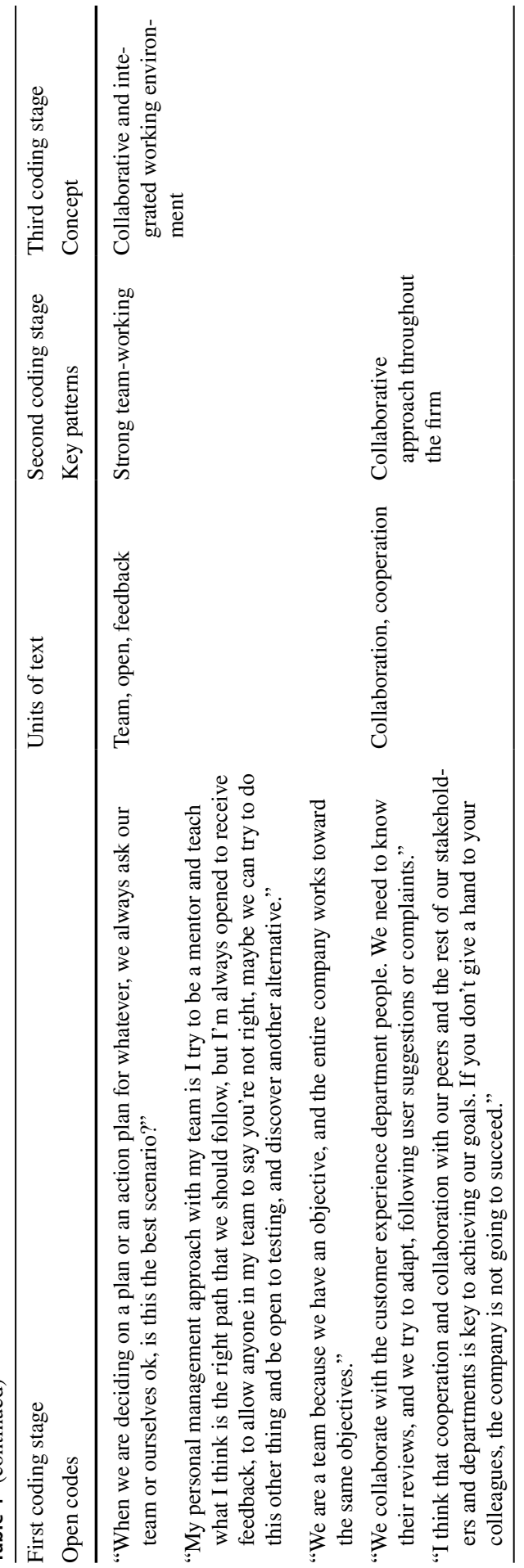




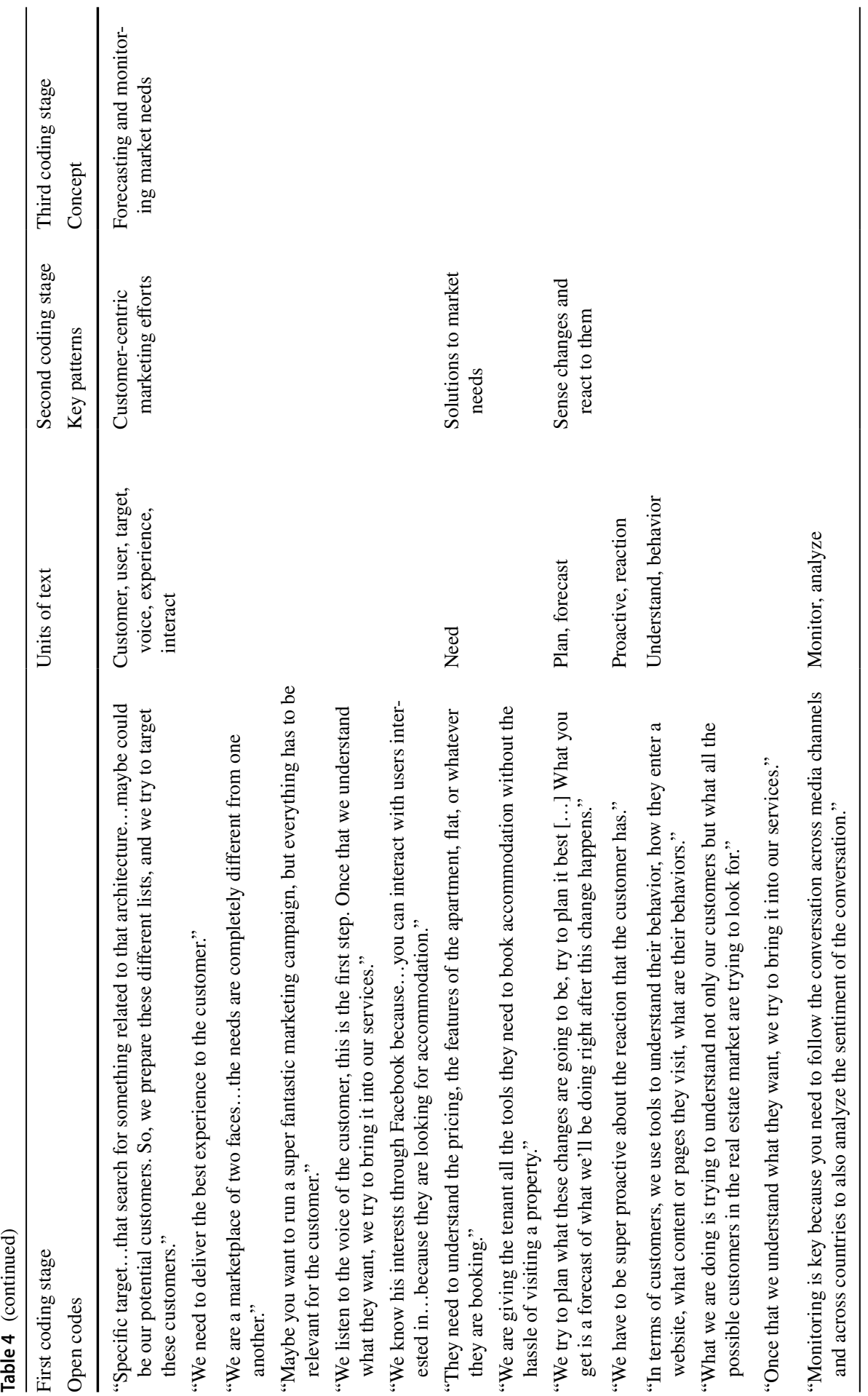




\subsection{Adaptability to changing conditions}

To ensure its product is easy for its customers to use, Spotahome relies strongly on a flexible and adaptive approach to accommodating changing customer needs and different international settings. On its Facebook page, we read "Serious company. I had a personal problem (my mother was in the hospital), and they activated the Cancellation Policy for Owners in the case of Force Majeure without any problems. Thank you very much!" This underlines the company's commitment to be flexible and to quickly adapt to the diverse needs and expectations of its customers who are looking for accommodations. Flexibility and adaptability are essential for such a business. The firm must also cope with the issue of seasonality affecting the rental market. Thus, the firm tries to adapt its product to a range of different periods (e.g., promoting September-October or January-February, when people are likely to move and change their accommodations more frequently). Hence, it focuses its marketing efforts differently according to how a firm's objectives change over time. The Head of Insights and Analytics claims:

"If you have an objective you have to adapt your task to these objectives. For example, if you have to change something but there are budget limitations, other activities have to be reduced to keep the same budget."

On its official website, Spotahome states, "we embrace simplicity" and "we get more from less," which suggests the firm strives to satisfy changing customer needs through flexible, rather than rigid planning; it invests resources, simplifies, and ensures frugality, all without implementing radical changes, rather optimizing in terms of money, time, and efforts. As the SEO manager claims:

"We try to make the Spotahome product available in as many geolocations as possible [...] You can search for an accommodation in Madrid [...], but maybe you are looking for an accommodation at a specific address, or next to whatever square, or in a neighborhood [...] We try to create or make the site as granular as possible [in terms of] geolocation entities [...] to adapt our product to people searching for [a particular type of] accommodation. We try to make life easier this way."

Emphasizing adaptability has helped the firm to develop an accessible product that flexibly adapts to various international contexts. As a global firm, Spotahome works to efficiently satisfy international customers' different expectations. The Head of Digital Performance Marketing states that,

"To reach the target necessary for Spotahome that complete our specific audience and interested to book an accommodation [...] we need to [use each user's] language [in] their country search [...]. Every time it's necessary to think about the audience, the user. The user is [in] a specific age [range], located in a specific city or country, and we need to speak their languages... so we need to be flexible and to adapt to the country of origin [...] From your sofa, you can book from Cagliari an accommodation in Madrid, in your lan- 
guage. So, we adapt for you our website, from the beginning until the payment method."

In summary, Spotahome continually tries to adapt to customers' expectations, which typically differ across countries. Also, the firm adapts its marketing campaigns to the user's language. For instance, in Belgium, people mainly speak Flemish (Dutch), German, English and French. Although Spotahome's website is not written in Dutch, they created some marketing campaigns in the Dutch language through remarketing, and impacted websites in Dutch on lifestyle and sport, aiming to convince the users to "come back" to Spotahome, and, thus, convert them into customers.

\subsection{Continual and fast pace of innovation}

By operating in a digital, international marketplace, Spotahome continuously undertakes initiatives to improve and innovate. Press releases retrieved from the firm's archival documents show that Spotahome attracted important funding in multiple rounds over the past years, to allow for expansion across more countries, and to invest in new product development to optimize digital services for tenants and property owners (landlords). Spotahome has a long-term vision, and being innovative is key to its performance, as declared by the Head of Insights and Analytics:

"We have to be at the forefront of technology... so we innovate all the time in technology, we innovate all the time in customer support, we innovate all the time in many things that... bring better support to customers."

Over the years, the firm has sought to bring innovation to the real estate industry. For instance, at the beginning of their business, Spotahome did not take $360^{\circ}$ photos of properties. Currently, this is one of its key strengths as it allows customers to visit homes virtually, with an experience that is close to "real." Furthermore, the firm has been working on influencer marketing campaigns, a practice seen more frequently in other industries such as fashion, involving "online entrepreneurs" also known as digital nomads (Johanson 2014). Digital nomads are tech-savvy, English-speaking, young people (MacRae 2016) who are highly popular on social media. Spotahome also aims to completely digitalize the rental process, including booking and digital transactions. The issue of payments is crucial for global firms to simplify monetary transactions from across the world.

From a practical perspective, constant attention to managing innovation is critical for the firm. As claimed by the SEO manager in charge of improving brand ranking on search engines (e.g., Google):

"We are always trying to make improvements on the website by making small changes,... launching new functionality on the website or testing a new channel, or whatever initiatives that we come up with within the company. We are always trying to launch them as fast as possible with minimum cost or effort." 


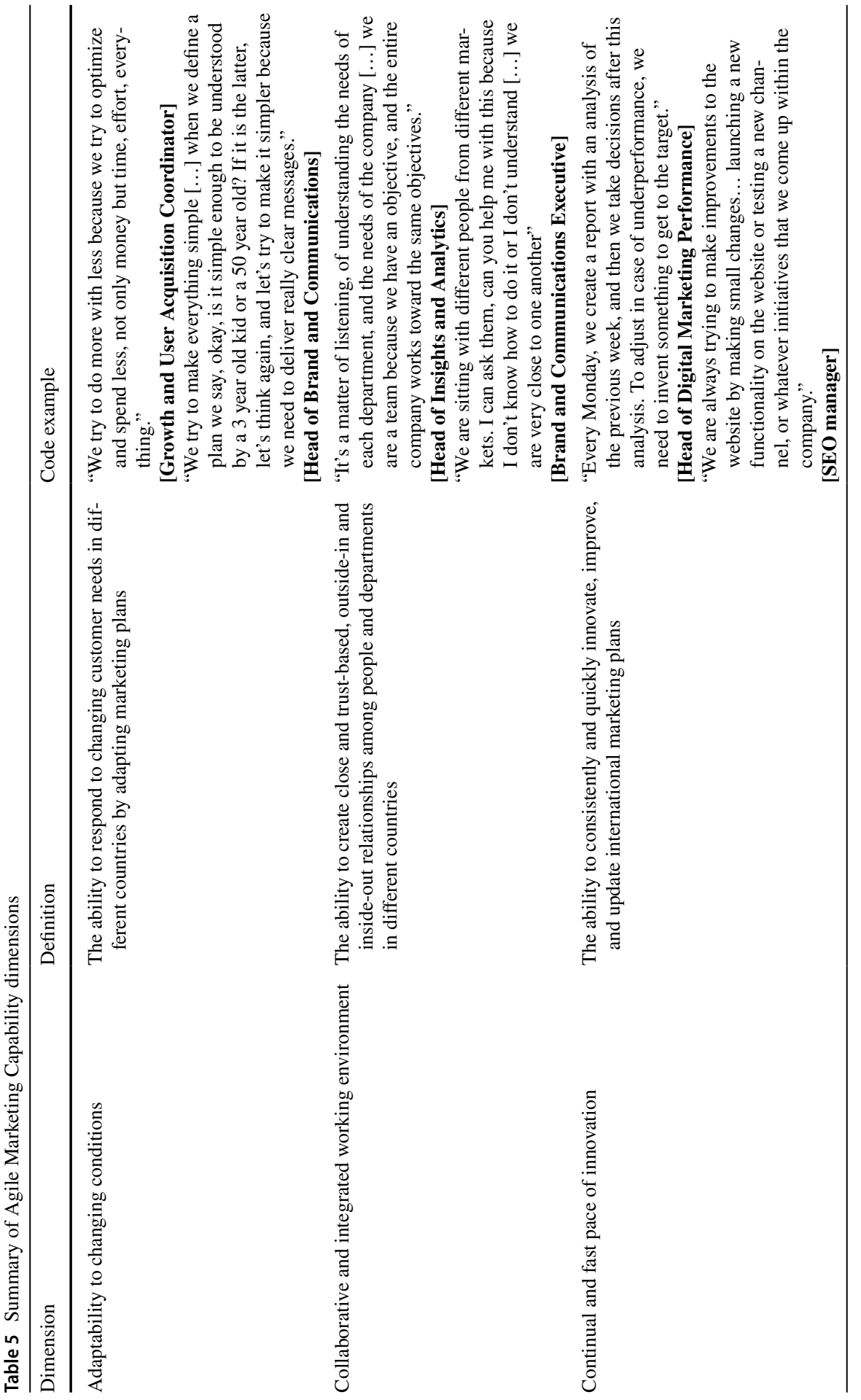









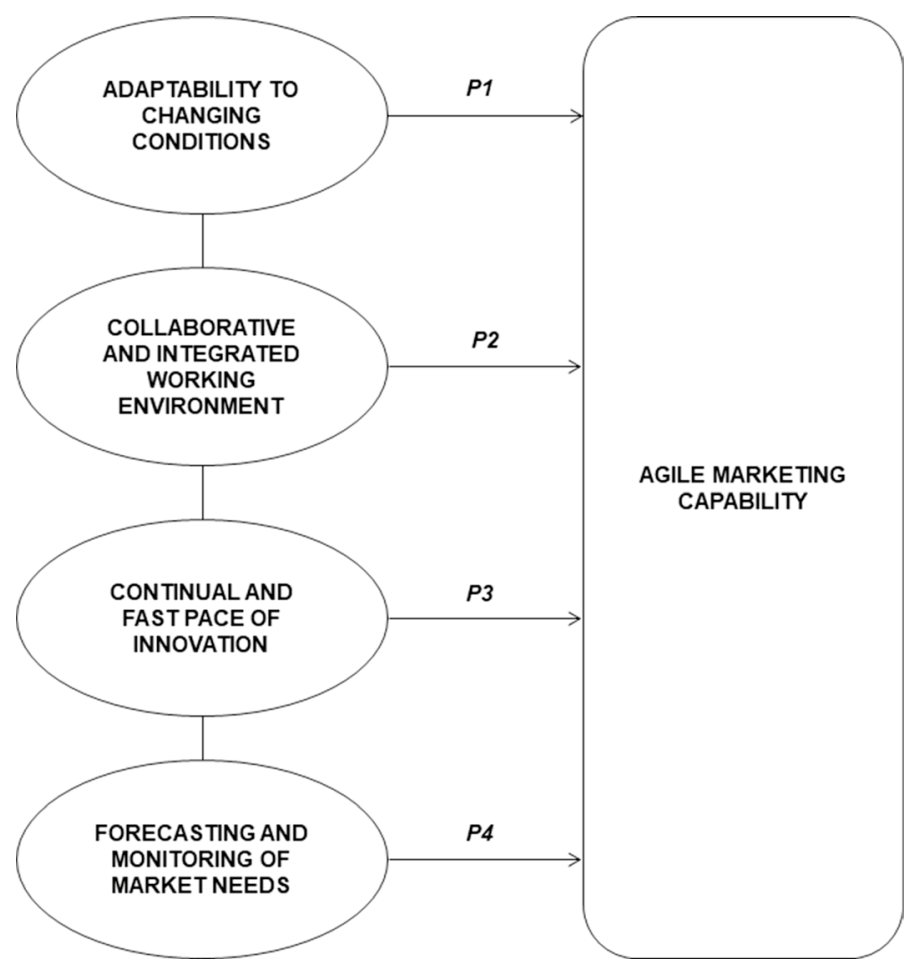

Fig. 1 The Agile Marketing Capability Framework

Managers create a weekly report analysis of customer behaviors-for example, how they click on the website and what content they select-to identify areas of "underperformance" and make decisions about how to reach their targets. They also analyze gains and losses in visibility in terms of keywords, cities, and targets, and try to make improvements. Furthermore, as an international business, these efforts to improve and innovate involve external freelancers in charge of the various countries. The firm defines a weekly plan to achieve a goal and conveys the changes to be implemented (e.g., a new promotion, discounts). If they want to improve efficiency, they communicate with the freelancers through Hangouts or e-mail to ask them to optimize. They constantly review the frictions that can arise among stakeholders (tenants and landlords) and seek to improve their product to reduce those frictions. This constant improvement, innovation, and optimization would not be feasible if Spotahome was sluggish in its responses. As stated by the Head of Brand and Communications:

"Our plans are shorter because we think in the mid-term instead of in the longterm [...], so the plans are shorter, and everything has to be relevant for the customer." 
Every plan represents a forecast of possible future scenarios. Accordingly, the marketing department, as well as the other departments, defines different quarterly plans for the main project areas according to their role (e.g., content for the website, link building, and Business Intelligence, and technical aspects of the website for the SEO manager). They also try to enhance speed by simplifying the way communication channels are managed. For instance, one team member covers all languages and a minimum of two channels.

\subsection{Collaborative and integrated working environment}

A key aspect of success in a digital, global context relates to collaboration, both internally and externally. As Spotahome asserts on its website, "we play a pivotal role in eliminating communication and language barriers between local landlords and foreign tenants by offering excellent customer support in several languages on both sides." The site also states "we are a team," "we live for the mission," and "we trust in trust." Such values highlight how supportive interactions and trust-based relationships are crucial in developing a working environment that allows Spotahome to build successful international marketing programs. The Head of Brand and Communications remarks:

"We need to think at a global level, and we need to cooperate on a global level. So every time that we have a success, we celebrate all together. And every time that we fail, we cry all together [...] I try to be a mentor and teach what is the right way that we should follow. Still, I'm always open to feedback, I allow anyone in my team area to say you're not right, maybe we can try to do this other thing and be open to testing, and discovering [a better] alternative."

Accordingly, success in marketing projects depends on cooperation and collaboration. Spotahome nurtures close and trust-based relationships within and among departments. The marketing team may collaborate with the product department to solve technical issues between the website and the platform, or with the customer experience team to learn about user suggestions or complaints from posted reviews. The marketing department also needs to interact with the design team regarding the creative aspects of advertisements, or with the insight team to gather data necessary to measure the effectiveness of promotions. The Brand and Communications Executive states:

"Spotahome's headquarter is in Spain [...] all the teams are located in the same building and the same place [...] I'm sitting with the other brand communication managers for other regions, for example, I have here the English one, the German one, the French one, so we talk all the time together because in marketing we are now structured like a function that gives service to the different regions, and we are a global marketing team."

Although decentralized decision-making, in which different people oversee different countries, is common in global firms, there is a strong intention to cooperate 
and work together, and these regional managers are situated next to each other, which simplifies the process of asking questions or seeking help.

A digital, global firm like Spotahome depends strongly on the use of technology in communication to foster an environment of close cooperation. For example, they use chatting tools for interacting, and sharing documents and links (e.g., Slack and Hipchat), and also have a weekly internal newsletter that delivers news and updates all departments. By leveraging technology, the firm strongly enhances information flow across the organization. When there is a meeting, information is loaded onto a chat box to promote transparent communication across the team. The CEO incentivizes this collaboration by providing weekly updates on the main achievements and targets for the departments. The Head of Insights and Analytics sums it up:

"Sometimes $[\ldots]$ you think that only the things you do are the right ones. It's a matter of listening, it's a matter of understanding the needs of each department, it's a matter of understanding the needs of the company, and if you can combine all that and [point] them in the same direction, it all goes well. So, we are a team because we have an objective, and [everyone in] the company works toward the same objectives."

\subsection{Forecasting and monitoring of market needs}

Finally, a key pillar of Spotahome is a completely customer-centric marketing approach, enabled by its $100 \%$ online platform. This approach is essential to delivering a superior customer experience, as repeatedly highlighted on their website. For example, their website states, "We work to teleport people into homes anywhere, so they can live the experience without being there. We connect with them. We bring reality to them," and "we are dedicated to providing the most enjoyable and stressfree housing search service. From booking to final confirmation, we're there for you!' Being customer-focused is critical to the firm's mission. The firm's Facebook page, where Spotahome offers help and guidelines to customers, states, "Are you planning to move to Berlin, but you don't know the city? We will guide you. We will help you to choose the place fit for your needs," or "Are you going to move to another city, but you don't have already found the right rental for you? We will help you to choose the perfect home!."

In particular, the firm is committed to continuously anticipating and responding to changes in customers' needs, to fulfill their expectations. Here IT plays a key role. As a digital business, Spotahome has the advantage of being able to analyze their customers' behaviors and motivations across touch points, and can use the data to optimize customer interactions and predict future behaviors. The Head of Brand and Communications asserts:

"You need to follow the conversation across media channels and across countries to ... analyze the sentiment of the conversation, [whether] ... it is positive or negative [or] neutral, and also the keywords that users are using. Users can use some wording, a specific messaging [...], and you have to switch your 
messages if yours have not delivered the proper idea or the proper description of the service that you are [providing]."

and also noted that,

"We have different metrics to measure ... satisfaction levels, and when those metrics go down a little bit, we put all efforts [in]to solv[ing] the situation [...] The customer has to be in the center. Not the brand, it's the customer. Not the company, it's the customer."

Spotahome tries to forecast customers' diverse needs so that it can offer a highly customized product. For example, landlords seek to increase income from their properties through quick rentals, whereas tenants seek accommodations in specific areas, with particular characteristics. The Spotahome platform is extremely useful for both landlords and tenants: landlords avoid the hassles of potential tenants visiting the property, as the tool allows homes to be rented in a couple of clicks. Tenants who are temporarily moving abroad obtain guaranteed, verified accommodations, with photos and videos of the properties. It is especially important for firms operating in foreign markets to be transparent, to manage different sets of expectations, and to ensure their customers' safety. Verification of rental properties is one of Spotahome's key strengths and is important in preventing scams.

Creating value for their customers is a top priority. Spotahome exploits technology to forecast and respond to customer needs proactively, applying technology to implement new features that meet and exceed customer expectations, and to adjust by correcting things that are not successful. They analyze group pages on Facebook that are dedicated to those seeking accommodation in their core markets, such as Madrid, London, Milan, and Rome, and contact these potential customers to offer customized solutions for them. These strategies are critical to success for technology-oriented firms that use digital tools to satisfy the expectations of customers internationally. Recalling the words of the Head of Digital Performance Marketing:

“There are specific audiences [identified] by Google, so we can't choose, it's something automatic, but it's able with the algorithm to understand when you put for example specific keywords like we are searching for some users interested in, specific target with this age, located in specific countries, cities, or neighborhoods, that search for something related to the architecture or garden, etc. [They] could be our potential customers. So, we prepare these different lists, and we try to target these customers."

Also,

"We can measure the journey funnel, so we know the number of people in the world interested in renting an accommodation [...] we try to convince them to book [...] we analyze this funnel, we use the Analytics as the first tool to analyze the traffic, the customer acquisition, and the behavior." 


\section{Discussion and theoretical contribution}

To succeed in today's dynamic, unpredictable and global business environment that is dominated by digitalization, the marketing function needs to employ agile principles. Despite the attention the topic is gaining, especially in the management and international marketing literature (e.g., Asseraf et al. 2019; Hagen et al. 2019; Li et al. 2019; Gomes et al. 2020), scholars have not analyzed and conceptualized the agility concept in terms of a specific marketing capability that enhances a firm's ability to adapt to a changing international and digital environment.

This study makes a contribution to the scholarly work by extending theories on dynamic capabilities and marketing capabilities by empirically examining and explaining how agile capabilities can be applied in a digital, international marketing context, and by proposing the Agile Marketing Capability. To date, scholars have paid little attention to how marketing efforts explicitly adapt to changing environments. Researchers have analyzed adaptive marketing capabilities (Day 2011; Guo et al. 2018; Moorman and Day 2016), while from a practical perspective there is increasing attention toward Agile Marketing approaches (Accardi-Petersen 2011; Gera et al. 2019; Poolton et al. 2006; van den Driest and Weed 2014). The conceptualization of the Agile Marketing Capability embraces a wider theoretical view, and proposes a capability that is more aligned with a highly competitive, international marketplace (Guo et al. 2018; Vaillant and Lafuente 2019). Explicitly, we define an Agile Marketing Capability as being characterized by a cross-functional collaboration of people, roles and departments that seeks to continuously renew, improve and innovate resources and capabilities to provide higher customer value by constantly sensing and responding to market changes through a flexible and adaptive approach.

Furthermore, this study extends the existing literature on agility in the international marketing domain by providing a theoretical framework in which to study the key dimensions that characterize an Agile Marketing Capability. Previous studies on international marketing agility focused on improving speed and accuracy (Vaillant and Lafuente 2019), or on being responsive and flexible (Hagen et al. 2019), forming the basis for developing international marketing agility. By responding to the need to understand how to develop agile actions that increase adaptability to fast-changing marketing conditions internationally (Gomes et al. 2020), this study identifies the following dimensions that characterize an Agile Marketing Capability: adaptability to changing conditions, collaborative and integrated working environment, continual and fast pace of innovation, and a focus on forecasting and monitoring market needs (see Fig. 1).

In this section, we elaborate on the contributions of this study by developing the four propositions that emerged from our analysis, offering them as the starting point for further research on this new line of inquiry.

\subsection{Adaptability to changing conditions}

Prior studies on agility have highlighted the relevance of an adaptive approach (Overby et al. 2006; Sheffi and Rice 2005) that competes with speed and surprise, 
adjusts strategies and redeploys resources flexibly (Gligor et al. 2013; Lu et al. 2011; Sambamurthy et al. 2003; Teece et al. 2016), and develops new products or diversifies existing product lines using existing facilities and supply chain (Eckstein et al. 2015; Swafford et al. 2006). In describing international marketing, prior studies have outlined a firm's ability to change direction and customize strategies in terms of the features that are most critical in international markets, i.e., flexibility (Asseraf et al. 2019; Gomes et al. 2020; Hagen et al. 2019; Li et al. 2019). This study extends the existing literature by showing that, when considered in a digital and international marketing context, an agile approach helps organizations to not only adjust their strategies in response to changes in the market but also implies a more effective use of resources and capabilities, by being more adaptive and flexible in dealing with the product demands in different countries. Indeed, our analysis shows that, in a digital, international marketing setting, adaptability manifests through flexible planning that places individuals at the center, and adjusts marketing plans to meet changing requirements. The case study that is the focus of our analysis reveals how the firm adapts to the seasonal nature of the rental market in meeting customers' preferences, and its commitment to adapting its objectives and reaching a global target market by using time, effort, and capital efficiently. Interestingly, the concept of adaptability is, in many ways, related to the pursuit of simplicity; in this case, by providing an easy search tool that makes renting a temporary home simple and accessible, in a way that adapts to the different expectations of customers across different countries. Thus, we advance our first proposition:

Proposition 1 (P1) An Agile Marketing Capability is grounded in adaptability to changing conditions, allowing marketing plans to quickly respond to changing international customer needs.

\subsection{Collaborative and Integrated Working Environment}

According to the literature, collaboration is crucial for agile practices to efficiently achieve a firm's objectives. Integrating and aligning IT throughout the supply chain enhances collaboration, which facilitates information flows (Ismail and Sharifi 2006; Kearns and Sabherwal 2006; Oh and Pinsonneault 2007; Tallon and Pinsonneault 2011). The international marketing literature on agility emphasizes a firm's ability to coordinate resources and activities among different stakeholders across foreign markets (Gomes et al. 2020; Hagen et al. 2019). By extending prior studies, this work emphasizes that being open to feedback and advice from others is essential for global marketing teams, helping to foster close and trust-based relationships both inside and outside the organization. Particularly for international businesses with a digital focus, the use of communication tools throughout the organization is critical to aligning business goals across teams and departments by disseminating up-to-date information on achievements and targets. This study reveals that an agile framework helps firms to foster that alignment, collaboration, and interaction among people and departments operating in different countries. An agile approach also promotes close, trust-based relationships, and a collaborative and stimulating working environment, 
empowers people and supports lean decision-making processes. These reflections lead to the following proposition:

Proposition 2 (P2) An Agile Marketing Capability is grounded in a collaborative and integrated working environment that creates close, trust-based relationships among individuals, departments and customers in different countries.

\subsection{Continual and fast pace of innovation}

Earlier studies claim that supply chain and IT agility involve the ability to continuously detect environmental changes and swiftly respond with innovative solutions (Chen et al. 2015; Gligor et al. 2013; Lu et al. 2011; Sambamurthy et al. 2003), such as by redeploying resources and quickly performing tasks (Li et al. 2009; Mandal 2018). Regarding international marketing agility, prior research highlights the necessity to "commit resources to allow the firms to rapidly adapt and change their strategies to the characteristics of the foreign market [...] to improve their planning procedures and implement marketing strategies that take into account the idiosyncrasies of the foreign market" (Gomes et al. 2020; p. 265). In other words, an Agile Marketing department must "allocate sufficient resources to underpin its continuous adaptation to changing and turbulent foreign markets" (Gomes et al. 2020; p. 265). By extending the prior literature, this study explains that agile firms foster insightful actions and strive to react decisively to changes, continually improving the speed and execution of their marketing tactics, operations, and planning. This study's findings show that continuous efforts to adopt cutting-edge technologies to investigate market trends, customer behaviors, and competition are crucial to providing optimized services and innovative responses to customer needs in various countries. Moreover, planning for the short or mid-term is essential to achieving greater speed in adjusting tasks by learning directly from customer insights, quickly improving strategic areas that are most relevant for customers, and rapidly updating marketing plans. Therefore, we formulate the following proposition:

Proposition 3 (P3) An Agile Marketing Capability is grounded in a continual and fast pace of innovation that consistently and quickly improves and updates international marketing plans.

\subsection{Forecasting and monitoring of market needs}

A large body of literature on agility focuses on responsiveness, that is, the ability to identify and respond to changes in supply chains, technology, competition, and demand reactively and proactively, and to recover from (Eckstein et al. 2015; Overby et al. 2006). By leveraging IT to facilitate customer information gathering (DeGroote and Marx 2013; Gligor et al. 2013; Kitchens et al. 2018), agility implies a greater ability to predict needs in the market and customize products and services to meet those needs (Ismail and Sharifi 2006; Lin et al. 2006; Roberts and Grover 
2012b; Sambamurthy et al. 2003). Previous international marketing studies refer to agility as a firm's ability to be responsive to foreign customers, i.e., to be speedy in detecting and addressing their needs and requirements (Gomes et al. 2020; Hagen et al. 2019). This study extends that stream of the literature, showing that by embedding agility in their marketing activities, organizations are not only able to identify and satisfy customers' needs, they are also able to respond to customers' requirements and expectations in a dynamic, timely and effective manner. This is possible because agile organizations continuously adopt up-to-date technologies and tools to address the range of customer needs in a timely manner. Indeed, our findings also reveal the importance of customer-oriented responsiveness triggered by technology in a marketing setting. We therefore propose that firms can forecast market needs at a global level using metrics for measuring customer satisfaction levels, by analyzing sentiments and other information across media channels and countries, thus offering more customized products. Our results also show a constant need to promote safety and transparency for the people in an organization. Our findings show that technology is vital in adopting proactive and reactive marketing strategies that improve customer satisfaction. We therefore propose the following:

Proposition 4 (P4) An Agile Marketing Capability is grounded in forecasting and monitoring of market needs by projecting the future characteristics of, and trends in international markets, enabling a firm to respond proactively or reactively to improve customer satisfaction.

\subsection{Managerial implications}

Although the present study provides an initial theoretical and empirical understanding of an Agile Marketing Capability, it offers crucial insights to increase managers' and practitioners' awareness of how to develop Agile Marketing capabilities, particularly those who operate in a digital-focused international context,.

The study's findings provide interesting, practical guidelines for managers and practitioners to learn how to employ agility in their marketing strategies and operations. Indeed, to be more competitive and more aligned with the challenges of digital transformation, companies should be trained to develop agile competencies in the marketing field, and to pursue faster, more flexible, and more customer-responsive marketing strategies and tactics. We provide practical guidelines for managers and practitioners in implementing Agile Marketing practices to achieve superior results.

Furthermore, the definitions of the key dimensions that characterize an Agile Marketing Capability can help managers and practitioners to be better informed when planning how to implement marketing-focused agile capabilities. In particular, this study advances the understanding of how agile practices can be applied in an international digital business, how to implement these practices to improve how digital technologies are exploited in marketing activities, and use agile approaches to increase customer satisfaction. 


\subsection{Limitation and future research}

Although our findings provide a good theoretical and empirical understanding of an Agile Marketing Capability, we acknowledge that the study is subject to limitations that could be addressed by researchers in the future.

Concerning the methodological approach, the single-case study method is appropriate for an in-depth analysis of a little explored phenomenon, but it is difficult to generalize and transfer the findings to other cases (Eisenhardt and Graebner 2007; Gomm et al. 2000). Hence, future research may investigate whether the study's conclusions can be extended to other organizational settings. Also, this study examined agility from the firm's perspective, without considering the customer point of view. Future research could extend this topic by looking at customers' perceptions of a firm's agility.

The results of this study are summarized into four theoretical propositions, which could be used as a starting point for further theoretical and empirical studies on this topic. Finally, we encourage future empirical measurements of our proposed framework for an Agile Marketing Capability. Future studies could advance measurement scales for the Agile Marketing Capability, and use the survey instrument to validate the findings.

Acknowledgements Ludovica Moi gratefully acknowledges Sardinian Regional Government for the financial support of her PhD scholarship (P.O.R. Sardegna F.S.E. - Operational Programme of the Autonomous Region of Sardinia, European Social Fund 2014-2020 - Axis III Education and training, Thematic goal 10, Investment Priority 10ii), Specific goal 10.5. She also gratefully acknowledges the University of Cagliari for the financial support of her research grant (MIUR - Progetto di sviluppo Dipartimentale di ECCELLENZA legge 232/2016 art. 1, commi 314-337 - annualità 2020 - CUP: F29E18000040001 Research project "Agile models for entrepreneurship").

Funding Open access funding provided by Università degli Studi di Cagliari within the CRUI-CARE Agreement.

Open Access This article is licensed under a Creative Commons Attribution 4.0 International License, which permits use, sharing, adaptation, distribution and reproduction in any medium or format, as long as you give appropriate credit to the original author(s) and the source, provide a link to the Creative Commons licence, and indicate if changes were made. The images or other third party material in this article are included in the article's Creative Commons licence, unless indicated otherwise in a credit line to the material. If material is not included in the article's Creative Commons licence and your intended use is not permitted by statutory regulation or exceeds the permitted use, you will need to obtain permission directly from the copyright holder. To view a copy of this licence, visit http://creativecommons.org/licen ses/by/4.0/.

\section{Appendix A: Semi-structured interview protocol}

Before starting with the interview, I would like to ask you some preliminary questions. Could you specify:

- Name

- Surname 
- How long have you been working in Spotahome?

- According to your role within the company, which are your main tasks or activities that you perform?

Q1. According to your opinion, and also on the basis of your experience at work during these years, which are the main changes that take place in Spotahome sector?

- Technological changes, changes in customer needs or preferences, new competitors? Other?

- What activities do you implement in accordance with these changes? (e.g., market monitoring, sector analysis, customer data collection) What are the specific tools that you use?

Q2. With respect to the competitors in the same or similar sectors at international level, what is in your opinion the key success factor or most representative aspect that enable Spotahome to succeed and be competitive at international level? Why?

- "We innovate to win," this is one of the values of Spotahome. What does it mean for you? In which way innovation is central for Spotahome competitive advantage?

Q3. On the basis of your experience at work, what are your customers looking for? What are their needs?

- Do you use specific channels/tools to communicate and interact with them? For example?

- Do you use specific tools to collect and analyze data of your customers? For example?

- Can you explain me the way or the procedure through which you try to satisfy customer needs?

Q4. Can you describe the procedure that you follow to change/update marketing plans?

- What are the key factors that you consider mostly to improve/optimize marketing plans or programs?

Q5. The mission of Spotahome basically concerns to make renting simple and fast, and offers the possibility for customers to live an experience without being there. Among the values the Spotahome supports there are "we embrace simplicity" and "we get more from less." On the basis of your role within the firm, could you describe me what do they mean these principles for you? Could you give me a practical example?

Q6. How do you use technology to communicate with customers? What type of relationship do you create with them? 
- Could you tell me an example of the way in which you interact with your customer on the basis of your current/past experience?

Q7. How do you use technology to communicate and coordinate your work with the other people within your department? Could you tell me an example of the way in which you use technology in this sense?

- Conversely, in which way do you use technology to communicate and coordinate your work with the other departments? Could you tell me an example of the way in which you use technology in this sense?

- Finally, how do you use technology to communicate and coordinate your work with the other departments located in different countries? Could you tell me an example of the way in which you use technology in this sense?

Q8. In its official website, among its key values Spotahome declares "we are a team." According to you, and also on the basis of your experience at work, what does it mean?

- Can you describe me what type of relationship do you have with the other people within your department? In which way do you work with marketing department? Can you describe how is a "normal" working day?

- What type of relationship do you have with the other departments? In which way to you work with them? For example?

- What type of relationship do you have with the other departments located in different countries? In which way to you work with them? For example?

\section{References}

Accardi-Petersen, M. (2011). How to get moving in Agile. New York: Springer.

Alford, P., \& Page, S. J. (2015). Marketing technology for adoption by small business. The Service Industries Journal, 35(11-12), 655-669.

Almor, T. (2011). Dancing as fast as they can: Israeli high-tech firms and the Great Recession of 2008. Thunderbird International Business Review, 53(2), 195-208.

Aronson, J. (1995). A pragmatic view of thematic analysis. The qualitative report, 2(1), 1-3.

Asseraf, Y., Lages, L. F., \& Shoham, A. (2019). Assessing the drivers and impact of international marketing agility. International Marketing Review, 36, 289-315.

Barkema, H. G., Baum, J. A., \& Mannix, E. A. (2002). Management challenges in a new time. Academy of Management Journal, 45(5), 916-930.

Barney, J. (1991). Firm resources and sustained competitive advantage. Journal of Management, 17(1), 99-120.

Barrales-Molina, V., Martínez-López, F. J., \& Gázquez-Abad, J. C. (2014). Dynamic marketing capabilities: Toward an integrative framework. International Journal of Management Reviews, 16(4), 397-416.

Bazeley, P., \& Jackson, K. (2013). Qualitative data analysis with NVivo. Sage Publications Limited.

Benbasat, I., Goldstein, D. K., \& Mead, M. (1987). The case research strategy in studies of information systems. MIS Quarterly, 11(3), 369-386. 
Bock, A. J., Opsahl, T., George, G., \& Gann, D. M. (2012). The effects of culture and structure on strategic flexibility during business model innovation. Journal of Management Studies, 49(2), 279-305.

Boyatzis, R. E. (1998). Transforming qualitative information: Thematic analysis and code development. New York: Sage.

Bruni, D. S., \& Verona, G. (2009). Dynamic marketing capabilities in Science-based firms: An exploratory investigation of the pharmaceutical industry. British Journal of Management, 20, S101-S117.

Bryman, A., \& Bell, E. (2015). Business research methods. Oxford, USA: Oxford University Press.

Chaffey, D. (2010). Applying organisational capability models to assess the maturity of digital-marketing governance. Journal of Marketing Management, 26(3-4), 187-196.

Chakravarty, A., Grewal, R., \& Sambamurthy, V. (2013). Information technology competencies, organizational agility, and firm performance: Enabling and facilitating roles. Information Systems Research, 24(4), 976-997.

Chen, Y., Wang, Y., Nevo, S., Benitez-Amado, J., \& Kou, G. (2015). IT capabilities and product innovation performance: The roles of corporate entrepreneurship and competitive intensity. Information \& Management, 52(6), 643-657.

Coleman, G., \& O'Connor, R. V. (2008). An investigation into software development process formation in software start-ups. Journal of Enterprise Information Management, 21(6), 633-648.

Conboy, K. (2009). Agility from first principles: Reconstructing the concept of agility in information systems development. Information Systems Research, 20(3), 329-354.

D'Aveni, R. A., Dagnino, G. B., \& Smith, K. G. (2010). The age of temporary advantage. Strategic Management Journal, 31(13), 1371-1385.

Daspit, J. J. (2017). D. Andreini and C. Bettinelli: Business model innovation: from systematic literature review to future research directions. Journal of Management \& Governance, 21(3), 785-792.

Day, G. S. (2011). Closing the marketing capabilities gap. Journal of Marketing, 75(4), 183-195.

Day, G. S. (2014). An outside-in approach to resource-based theories. Journal of the Academy of Marketing Science, 42(1), 27-28.

DeGroote, S. E., \& Marx, T. G. (2013). The impact of IT on supply chain agility and firm performance: An empirical investigation. International Journal of Information Management, 33(6), 909-916.

Dubé, L., \& Paré, G. (2003). Rigor in information systems positivist case research: current practices, trends, and recommendations. MIS quarterly, 597-636.

Dubey, R., Altay, N., Gunasekaran, A., Blome, C., Papadopoulos, T., \& Childe, S. J. (2018). Supply chain agility, adaptability and alignment: empirical evidence from the Indian auto components industry. International Journal of Operations \& Production Management, 38(1), 129-148.

Dyer, W. G., Jr., \& Wilkins, A. L. (1991). Better stories, not better constructs, to generate better theory: A rejoinder to Eisenhardt. Academy of Management Review, 16(3), 613-619.

Eckstein, D., Goellner, M., Blome, C., \& Henke, M. (2015). The performance impact of supply chain agility and supply chain adaptability: the moderating effect of product complexity. International Journal of Production Research, 53(10), 3028-3046.

Edmondson, A. C., \& McManus, S. E. (2007). Methodological fit in management field research. Academy of Management Review, 32(4), 1246-1264.

Eisenhardt, K. M. (1989). Building theories from case study research. Academy of Management Review, 14(4), 532-550.

Eisenhardt, K. M., \& Graebner, M. E. (2007). Theory building from cases: Opportunities and challenges. The Academy of Management Journal, 50(1), 25-32.

Ewel, J. (2013). Getting Started With Agile Marketing. Retrieved from https://www.agilemarketing.net/ GettingStartedWithAgileMarketing.pdf

Falasca, M., Zhang, J., Conchar, M., \& Li, L. (2017). The impact of customer knowledge and marketing dynamic capability on innovation performance: an empirical analysis. Journal of Business Industrial Marketing, 32, 901-912.

Fang, E. E., \& Zou, S. (2009). Antecedents and consequences of marketing dynamic capabilities in international joint ventures. Journal of International Business Studies, 40(5), 742-761.

Felipe, C. M., Roldán, J. L., \& Leal-Rodríguez, A. L. (2016). An explanatory and predictive model for organizational agility. Journal of Business Research, 69(10), 4624-4631.

Fitzgerald, M., Kruschwitz, N., Bonnet, D., \& Welch, M. (2014). Embracing digital technology: A new strategic imperative. MIT Sloan Management Review, 55, 2.

Fontana, A., \& Frey, J. H. (2000). The interview: From structured questions to negotiated text. Handbook of Qualitative Research, 2(6), 645-672. 
Gera, G., Gera, B., \& Mishra, A. (2019). Role of Agile marketing in the present era. International Journal of Technical Research \& Science, 4(5), 40-44.

Gibbs, G. R. (2007). Thematic coding and categorizing. Analyzing qualitative data (pp. 38-56). London: Sage.

Gligor, D. M., Holcomb, M. C., \& Stank, T. P. (2013). A multidisciplinary approach to supply chain agility: Conceptualization and scale development. Journal of business logistics, 34(2), 94-108.

Goldman, S. L. (1995). Agile competitors and virtual organizations: strategies for enriching the customer. Van Nostrand Reinhold Company.

Golgeci, I., \& Gligor, D. M. (2017). The interplay between key marketing and supply chain management capabilities: the role of integrative mechanisms. Journal of Business \& Industrial Marketing, 32(3), 472-483.

Gomes, E., Sousa, C. M., \& Vendrell-Herrero, F. (2020). International marketing agility: Conceptualization and research agenda. International Marketing Review, 37, 261-272.

Gomm, R., Hammersley, M., \& Foster, P. (2000). Case study and generalization. In R. Gomm, M. Hammersley, \& P. Foster (Eds.), Case study method (pp. 98-116). London: SAGE.

Gren, L., Torkar, R., \& Feldt, R. (2015). The prospects of a quantitative measurement of agility: A validation study on an agile maturity model. Journal of Systems and Software, 107, 38-49.

Grewal, R., \& Tansuhaj, P. (2001). Building organizational capabilities for managing economic crisis: The role of market orientation and strategic flexibility. Journal of marketing, 65(2), 67-80.

Guo, H., Xu, H., Tang, C., Liu-Thompkins, Y., Guo, Z., \& Dong, B. (2018). Comparing the impact of different marketing capabilities: Empirical evidence from B2B firms in China. Journal of Business Research, 93, 79-89.

Hagen, B., Zucchella, A., \& Ghauri, P. N. (2019). From fragile to agile: marketing as a key driver of entrepreneurial internationalization. International Marketing Review, 36, 260-288.

Hess, T., Matt, C., Benlian, A., \& Wiesböck, F. (2016). Options for formulating a digital transformation strategy. MIS Quarterly Executive, 15(2), 123-139.

Hoegl, M., \& Gemuenden, H. G. (2001). Teamwork quality and the success of innovative projects: A theoretical concept and empirical evidence. Organization Science, 12(4), 435-449.

Hoffman, R., Casnocha, B., \& Yeh, C. (2013). Tours of duty: The new employer-employee compact. Harvard Business Review, 91(6), 49-58.

Hult, G. T. M., Ketchen, D. J., Jr., \& Slater, S. F. (2005). Market orientation and performance: an integration of disparate approaches. Strategic Management Journal, 26(12), 1173-1181.

Ismail, H. S., \& Sharifi, H. (2006). A balanced approach to building agile supply chains. International Journal of Physical Distribution \& Logistics Management, 36(6), 431-444.

Jaakkola, M., Möller, K., Parvinen, P., Evanschitzky, H., \& Mühlbacher, H. (2010). Strategic marketing and business performance: A study in three European 'engineering countries'. Industrial Marketing Management, 39(8), 1300-1310.

Jain, S. C. (1989). Standardization of international marketing strategy: some research hypotheses. The Journal of Marketing, 53(1), 70-79.

Johanson, M. (2014). For digital nomads, work is no longer a place and life is one big adventure. International Business Times.

Kearns, G. S., \& Sabherwal, R. (2006). Strategic alignment between business and information technology: a knowledge-based view of behaviors, outcomes, and consequences. Journal of management information systems, 23(3), 129-162.

Khan, H. (2020). Is marketing agility important for emerging market firms in advanced markets? International Business Review.

Killian, G., \& McManus, K. (2015). A marketing communications approach for the digital era: Managerial guidelines for social media integration. Business Horizons, 58(5), 539-549.

Kitchens, B., Dobolyi, D., Li, J., \& Abbasi, A. (2018). Advanced Customer Analytics: Strategic Value Through Integration of Relationship-Oriented Big Data. Journal of Management Information Systems, 35(2), 540-574.

Kumar, N., Stern, L. W., \& Anderson, J. C. (1993). Conducting interorganisational research using key informants. Academy of Management Journal, 36(6), 1633-1651.

Li, X., Goldsby, T. J., \& Holsapple, C. W. (2009). Supply chain agility: scale development. The International Journal of Logistics Management, 20(3), 408-424.

Li, R., Liu, Y., \& Bustinza, O. F. (2019). FDI, service intensity, and international marketing agility: The case of export quality of Chinese enterprises. International Marketing Review, 36(2), 213-238. 
Lin, C.-T., Chiu, H., \& Chu, P.-Y. (2006). Agility index in the supply chain. International Journal of Production Economics, 100(2), 285-299.

Lincoln, Y. S., \& Guba, E. G. (2013). The Constructivist Credo. Walnut Creek, CA: Left Coast Press.

Lu, Y., \& Ramamurthy, K. (2011). Understanding the link between information technology capability and organizational agility: An empirical examination. MIS Quarterly, 35(4), 931-954.

MacRae, G. (2016). Community and cosmopolitanism in the new Ubud. Annals of Tourism Research, 59, $16-29$.

Mandal, S. (2018). An examination of the importance of big data analytics in supply chain agility development: A dynamic capability perspective. Management Research Review, 41(10), 1201-1219.

Matthyssens, P., Pauwels, P., \& Vandenbempt, K. (2005). Strategic flexibility, rigidity, and barriers to the development of absorptive capacity in business markets: Themes and research perspectives. Industrial Marketing Management, 34(6), 547-554.

Merrilees, B., Rundle-Thiele, S., \& Lye, A. (2011). Marketing capabilities: Antecedents and implications for B2B SME performance. Industrial Marketing Management, 40(3), 368-375.

Miles, A. (2013). Agile learning: Living with the speed of change. Development and Learning in Organizations: An International Journal, 27(2), 20-22.

Miles, M. B., \& Huberman, A. M. (1984). Qualitative data analysis: A sourcebook of new methods. Qualitative data analysis: A sourcebook of new methods. London: Sage publications.

Mithas, S., Ramasubbu, N., \& Sambamurthy, V. (2011). How information management capability influences firm performance. MIS Quarterly, 35(1), 237-256.

Moi, L., Frau, M., \& Cabiddu, F. (2018). Exploring the Role of Nvivo software in Marketing Research. Mercati \& Competitività, 4, 65-86.

Moorman, C., \& Day, G. S. (2016). Organizing for marketing excellence. Journal of Marketing, 80(6), $6-35$.

$\mathrm{Mu}$, J. (2015). Marketing capability, organizational adaptation and new product development performance. Industrial Marketing Management, 49, 151-166.

Myers, M. D. (2013). Qualitative research in business and management. London: Sage.

Nemkova, E. (2017). The impact of agility on the market performance of born-global firms: An exploratory study of the 'Tech City'innovation cluster. Journal of Business Research, 80, 257-265.

O'Keeffe, A., Ozuem, W., \& Lancaster, G. (2016). Leadership marketing: an exploratory study. Journal of Strategic Marketing, 24(5), 418-443.

Oh, W., \& Pinsonneault, A. (2007). On the assessment of the strategic value of information technologies: conceptual and analytical approaches. MIS Quarterly, 239-265.

Onetti, A., Zucchella, A., Jones, M. V., \& McDougall-Covin, P. P. (2012). Internationalization, innovation, and entrepreneurship: business models for new technology-based firms. Journal of Management and Governance, 16(3), 337-368.

Orlandi, L. B. (2016). Organizational capabilities in the digital era: Reframing strategic orientation. Journal of Innovation \& Knowledge, 1(3), 156-161.

Overby, E., Bharadwaj, A., \& Sambamurthy, V. (2006). Enterprise agility and the enabling role of information technology. European Journal of Information Systems, 15(2), 120-131.

Panda, S., \& Rath, S. K. (2017). The effect of human IT capability on organizational agility: an empirical analysis. Management Research Review, 40(7), 800-820.

Pantiuchina, J., Mondini, M., Khanna, D., Wang, X., \& Abrahamsson, P. (2017). Are software startups applying agile practices? The state of the practice from a large survey. International Conference on Agile Software Development, Springer, Cham, pp. 167-183.

Patton, M. Q. (2014). Qualitative research \& evaluation methods (4th edn). Thousand Oaks, CA: SAGE Publishing.

Piccoli, G., \& Ives, B. (2005). IT-dependent strategic initiatives and sustained competitive advantage: a review and synthesis of the literature. MIS quarterly, 29(4), 747-776.

Piekkari, R., Welch, C., \& Paavilainen, E. (2009). The case study as disciplinary convention: Evidence from international business journals. Organizational Research Methods, 12(3), 567-589.

Pikkarainen, M., Haikara, J., Salo, O., Abrahamsson, P., \& Still, J. (2008). The impact of agile practices on communication in software development. Empirical Software Engineering, 13(3), 303-337.

Poolton, J., Ismail, H. S., Reid, I. R., \& Arokiam, I. C. (2006). Agile marketing for the manufacturingbased SME. Marketing Intelligence \& Planning, 24(7), 681-693. 
Ravichandran, T. (2018). Exploring the relationships between IT competence, innovation capacity and organizational agility. The Journal of Strategic Information Systems, 27(1), 22-42.

Recker, J., Holten, R., Hummel, M., \& Rosenkranz, C. (2017). How agile practices impact customer responsiveness and development success: A field study. Project Management Journal, 48(2), 99-121.

Ries, E. (2011). The lean startup: How today's entrepreneurs use continuous innovation to create radically successful businesses. Crown Books.

Rigby, D. K., Sutherland, J., \& Takeuchi, H. (2016). Embracing agile. Harvard Business Review, 94(5), 40-50.

Roberts, N., \& Grover, V. (2012a). Investigating firm's customer agility and firm performance: The importance of aligning sense and respond capabilities. Journal of Business Research, 65(5), $579-585$.

Roberts, N., \& Grover, V. (2012b). Leveraging information technology infrastructure to facilitate a firm's customer agility and competitive activity: An empirical investigation. Journal of Management Information Systems, 28(4), 231-270.

Robson, C. (1993). Real world research: A resource for social scientists and practitioners-researchers. Massachusetts: Blackwell Pushers.

Rogers, D. L. (2016). The digital transformation playbook: Rethink your business for the digital age. Columbia University Press.

Saeed, S., Yousafzai, S., Paladino, A., \& De Luca, L. M. (2015). Inside-out and outside-in orientations: A meta-analysis of orientation's effects on innovation and firm performance. Industrial Marketing Management, 47, 121-133.

Sambamurthy, V., Bharadwaj, A., \& Grover, V. (2003). Shaping agility through digital options: Reconceptualizing the role of information technology in contemporary firms. MIS quarterly, 237-263.

Sangari, M. S., \& Razmi, J. (2015). Business intelligence competence, agile capabilities, and agile performance in supply chain: An empirical study. The International Journal of Logistics Management, 26(2), 356-380.

Sebastian, I. M., Ross, J. W., Beath, C., Mocker, M., Moloney, K. G., \& Fonstad, N. O. (2017). How Big Old Companies Navigate Digital Transformation. MIS Quarterly Executive.

Seidman, I. (2013). Interviewing as qualitative research: A guide for researchers in education and the social sciences. Teachers college press.

Shah, S. K., \& Corley, K. G. (2006). Building better theory by bridging the quantitative-qualitative divide. Journal of Management Studies, 43, 1821-1835.

Sheffi, Y., \& Rice, J. B., Jr. (2005). A supply chain view of the resilient enterprise. MIT Sloan management review, 47(1), 41.

Silverman, D. (2013). Doing qualitative research: A practical handbook. SAGE Publications Limited.

Smart, R. (2016). The Agile Marketer: Turning Customer Experience Into Your Competitive Advantage. John Wiley \& Sons.

Stake, R. E. (1995). The art of case study research. Sage.

Stone, B. (2013). The everything store: Jeff Bezos and the age of Amazon. Random House.

Stone, B. (2017). The Upstarts: How Uber, Airbnb and the Killer Companies of the New Silicon Valley are Changing the World. Random House.

Strauss, A., \& Corbin, J. M. (1998). Basics of Qualitative Research: Techniques and Procedures for Developing Grounded Theory. London: Sage Publications.

Swafford, P. M., Ghosh, S., \& Murthy, N. (2006). The antecedents of supply chain agility of a firm: scale development and model testing. Journal of Operations Management, 24(2), 170-188.

Tahmasebifard, H., Zangoueinezhad, A., \& Jafari, P. (2017). The Role of Entrepreneurial Orientation in Achieving Agility Capability. Journal of Applied Economics \& Business Research, 7(2), 137-156.

Tallon, P. P., \& Pinsonneault, A. (2011). Competing perspectives on the link between strategic information technology alignment and organizational agility: insights from a mediation model. MIS Quarterly, 35(2), 463-486.

Taylor, S. J., Bogdan, R., \& DeVault, M. (2015). Introduction to qualitative research methods: A guidebook and resource. New York: Wiley.

Teece, D., Peteraf, M., \& Leih, S. (2016). Dynamic capabilities and organizational agility: Risk, uncertainty, and strategy in the innovation economy. California Management Review, 58(4), $13-35$. 
Teece, D. J., Pisano, G., \& Shuen, A. (1997). Dynamic capabilities and strategic management. Strategic Management Journal, 18(7), 509-533.

Theodosiou, M., \& Leonidou, L. C. (2003). Standardization versus adaptation of international marketing strategy: an integrative assessment of the empirical research. International business review, 12(2), 141-171.

Vaillant, Y., \& Lafuente, E. (2019). The increased international propensity of serial entrepreneurs demonstrating ambidextrous strategic agility. International Marketing Review, 36, 239-259.

Van den Driest, F., \& Weed, K. (2014). The ultimate marketing machine. Harvard Business Review, 92(7-8), 54-63.

Van Teijlingen, E. R., Rennie, A.-M., Hundley, V., \& Graham, W. (2001). The importance of conducting and reporting pilot studies: the example of the Scottish Births Survey. Journal of Advanced Nursing, 34(3), 289-295.

Vendrell-Herrero, F., Bustinza, O. F., Parry, G., \& Georgantzis, N. (2017). Servitization, digitization and supply chain interdependency. Industrial Marketing Management, 60, 69-81.

Wagner, H.-T., Beimborn, D., \& Weitzel, T. (2014). How social capital among information technology and business units drives operational alignment and IT business value. Journal of Management Information Systems, 31(1), 241-272.

Xu, H., Guo, H., Zhang, J., \& Dang, A. (2018). Facilitating dynamic marketing capabilities development for domestic and foreign firms in an emerging economy. Journal of Business Research, 86, $141-152$.

Yin, R. K. (1994). Case Study Research: Design and Methods (Applied Social Research Methods, Vol. 5). Sage Publications, Beverly Hills, CA. Rick Rantz Leading urban institutions of higher education in the new millennium Leadership \& Organization Development Journal, 23(8), 2002.

Yin, R. K. (2009). Case study research: Design and methods (applied social research methods). London and Singapore: Sage.

Zhou, J., Bi, G., Liu, H., Fang, Y., \& Hua, Z. (2018). Understanding employee competence, operational IS alignment, and organizational agility-An ambidexterity perspective. Information \& Management, 55(6), 695-708.

Publisher's Note Springer Nature remains neutral with regard to jurisdictional claims in published maps and institutional affiliations.

Ludovica Moi has obtained her PhD in Economics and Business Sciences at the University of Cagliari (Italy). Currently, she is Postdoctoral Research Fellow at the University of Cagliari. Her research interests focus the new frontiers of marketing driven by digital technologies, in particular Agile Marketing capabilities.

Francesca Cabiddu is Full Professor at Università degli Studi di Cagliari (Italy). Her research expertise is in marketing and the use of IT to support customer service and engagement in the services sector. Her research has appeared in Annals of tourism Research, Business Horizon, The Service Industries Journal, Industrial Marketing Management, Journal of Service Research as well as other academic and applied journals. 